Goldschmidt 2021 Abstract

https://doi.org/10.7185/gold2021.5880

\section{Occurrence of anaerobic ammonium oxidation (anammox) in the eastern Mediterranean Sea over the last 56 \\ kyr}

\author{
ZOË R. VAN KEMENADE ${ }^{1}$, RICK HENNEKAM ${ }^{2}$, \\ MARCEL VAN DER MEER ${ }^{1}$, ELLEN C. HOPMANS ${ }^{1}$, \\ LAURA VILLANUEVA ${ }^{1,3}$, JAAP S. SINNINGHE \\ DAMSTÉ $^{1,3}$ AND DARCI RUSH ${ }^{1}$
}

${ }^{1}$ NIOZ Royal Netherlands Institute for Sea Research

${ }^{2}$ NIOZ-Royal Netherlands Institute for Sea Research

${ }^{3}$ Faculty of Geosciences, Utrecht University

Presenting Author: zoe.van.kemenade@nioz.nl

In the eastern Mediterranean Sea, the typically organic-poor sedimentary record is alternated with organic-rich sediment layers, known as sapropels. The cyclic occurrence of sapropels is associated with insolation-driven freshwater forcing, causing water-column stratification and enhanced nutrient input. This resulted in episodically basin-wide anoxia of the eastern Mediterranean Sea [1]. Anaerobic ammonium oxidizing (anammox) bacteria have shown to be responsible for major losses of bioavailable nitrogen $(\mathrm{N})$ in the modern anoxic ocean. Yet, it remains unknown what the importance is of $\mathrm{N}$ removal by anammox during the large-scale deoxygenation events, associated with eastern Mediterranean sapropel intervals. Anammox bacteria uniquely synthesize ladderane lipids [2]. In addition, marine anammox uniquely synthesize a stereoisomer of bacteriohopanetetrol (BHT-x) [3]. These lipid biomarkers can thus be used to assess anammox during past deoxygenation events. At present, a detailed record covering the onset, duration and termination of deposition of the most recent sapropel (S1) is still lacking. Here, we investigate the presence of BHT- $x$ and ladderane fatty acids (FAs) in a high-resolution $\sim 56 \mathrm{kyr}$ sedimentary record, recovered from the Levantine Basin $\left(33^{\circ} 18^{\prime} \mathrm{N}, 33^{\circ} 24^{\prime} \mathrm{E}\right)$, covering sapropel S1 ( 10.5-6.1 kyr BP). BHT- $x$ abundance increased rapidly preceding the onset of $\mathrm{S} 1$ deposition and remained high throughout S1. Occurrence of marine anammox is confirmed by high abundances of ladderane FAs at the same S1 sediment depths, with maximum concentrations corresponding to peak BHT- $x$ values. A lag of $2.6 \mathrm{kyr}$ is observed between peak anammox biomarker concentrations ( $7.8 \mathrm{cal}$. kyr) and TOC values (9.9 cal. kyr). This may suggest that increased removal of bioavailable $\mathrm{N}$ by anammox may have been important for the reduced organic carbon production during later stages within S1. Strongly depleted bulk $\delta^{15} \mathrm{~N}$ values occur only during the onset of $\mathrm{S} 1$ depositions, when TOC is highest, indicating enhanced $\mathrm{N}$ fixation at this time. Our results highlight the role of anammox in bioavailable $\mathrm{N}$ removal during sapropel formation, hereby potentially quenching primary production and providing a negative feedback for deoxygenation events.

References:

[1] Rohling et al., (2015). Earth-Science Reviews, 143, 62-97.

[2] Sinninghe Damsté et al., (2002). Nature,419(6908), 708
712.

[3]Schwartz-Narbonne et al., (2020). Organic Geochemistry, 143. 